
J. Beneke
C. Hayworth
R. Hobson
Z. Mia

\title{
Examining the effect of retail service quality dimensions on customer satisfaction and loyalty: The case of the supermarket shopper
}

\author{
Justin Beneke: School of Management Studies, Faculty of Commerce, University of Cape Town \\ Claire Hayworth: School of Management Studies, Faculty of Commerce, University of Cape Town \\ Robyn Hobson: School of Management Studies, Faculty of Commerce, University of Cape Town \\ Zeenat Mia: School of Management Studies, Faculty of Commerce, University of Cape Town
}

\begin{abstract}
Purpose: Post Apartheid, the South African supermarket sector has rapidly increased in size and stature, yet customer satisfaction and fostering goodwill don't appear to have kept pace with growth. This research considers which aspects of retail service quality impact upon customer satisfaction and, ultimately, pay dividends in terms of generating store loyalty amongst urban shoppers in the middle to upper market segments.

Design/methodology/approach: A survey approach was used to collect data from 307 respondents within a major metro pole area, as well as through an online interface. This was used to test our path model using Partial Least Squares (PLS) analysis.

Findings: The results from the analysis concluded that two constructs, namely Physical Aspects and Personal Interaction, had a direct relationship with Customer Satisfaction. Customer satisfaction was also confirmed to be positively linked to store loyalty.

Originality/Value: This research uncovers which aspects of service are most coveted by consumers in an emerging market context, as well as their effect on generating repeat business. If supermarket chains are to move beyond mere profit generation and build meaningful relationships with customers, they would best be advised to focus on the attributes of service that have a direct bearing on customer satisfaction and, in turn, long-term repeat patronage.
\end{abstract}

Keywords: grocery, supermarket, service quality, satisfaction, loyalty, PLS

\section{INTRODUCTION}

The current market place has become more competitive as customers continually expect retailers to match or exceed their expectations (Wong and Sohal, 2003). With a rising degree of homogeneity between merchandise offerings, supermarkets are increasingly turning to the delivery of effective customer services to render a competitive advantage (Ellram et al, 1999). Maintaining customer satisfaction is crucial for such retailers as they transact in a highly competitive world (Fonseca, 2009).

The South African supermarket sector contains a handful of large supermarket chains which dominate the local retailing space. In this respect, Shoprite, Pick n Pay, Spar, Checkers and Woolworths are thought to control the supermarket trading environment in South Africa and are frequently referred to as the 'Big Five'.

Store loyalty is an extremely important financial consideration for all supermarkets (Knox and Denison, 2000), as acquiring new customers is expensive due to advertising, promotional, and start-up operating expenses. Likewise, loyal customers exhibit increased repurchase intentions, a decrease in price sensitivity, and positive word of mouth communications (Varela-Neira et al, 2010). It is therefore more economical to serve current customers (Tepeci, 1999). In South Africa, saturation in the grocery sector has meant that the competition for customers is particularly fierce. As room for organic growth dissipates, these retailers are being forced to turn their attention sharply towards fostering goodwill and customer loyalty (Martinez-Ruiz et al, 2010).

Although the relationships between retail service quality, customer satisfaction and loyalty are argued to be well understood in some quarters, there is still much scope for further research in this regard (Bodet, 2008). Such work has been set in motion in South Africa by Marx and Erasmus (2006), who examined 


\section{J. Beneke \\ C. Hayworth \\ R. Hobson \\ Z. Mia}

Examining the effect of retail service quality dimensions on customer satisfaction and loyalty: The case of the supermarket shopper

customer service in the Tshwane Metropolis. This study aims to build on their research by assuming a wider perspective.

\section{RESEARCH STATEMENT}

Since the end of Apartheid in 1994, the South African supermarket sector has grown exponentially. This is partly due to an increase in real mean per capita income, facilitated by a burgeoning middle class. However, acquiring and maintaining loyal customers is argued to be fundamental to ensuring profitability. This study aims to investigate the antecedents of customer satisfaction in the supermarket sector, as well as their ultimate influence on store loyalty. In this respect, the research aims to establish the drivers of customer satisfaction, through a consideration of retail service quality dimensions, and the follow through effect on store loyalty in the South African supermarket sector. This should empower retailers to make the necessary trade-offs to ensure that their businesses are geared towards capitalising on the attributes of consumer behaviour which lead to elevated levels of affinity towards the chain.

\section{LITERATURE REVIEW}

\section{Customer Satisfaction}

Early customer satisfaction research typically defined satisfaction as a post-choice evaluative judgment concerning a specific purchase decision (Homburg and Giering, 2001). Additional research into customer satisfaction claims that satisfaction should be viewed as a judgment based on cumulative experience with a particular product or service rather than a transaction specific encounter (Anderson et al., 1994). Tse and Wilton (1988) suggested that satisfaction is a general psychological phenomenon, describing the emotional state resulting from an evaluation of the perceived discrepancy between prior expectations and actual performance of the product or service.

Many individual companies, industries, and even countries monitor customer satisfaction on a continual basis (Fornell, 1992). Customer satisfaction is an important construct as satisfaction is a critical measure of a firm's success (Fonseca, 2009). The level of customer satisfaction has been shown to influence attitude and word of mouth communication (Sivadas and Baker-Prewitt, 2000); to be a good predictor of future purchase behaviour (Garbarino and Johnson, 1999; Kasper, 1988); to influence profit (Anderson et al., 1994); and, in the long run, to lead to store loyalty (Oliver, 2010). Furthermore, Huber et al. (2001) found satisfied customers are willing to pay premium prices.

There appears to be perpetual interest in customer satisfaction as a means of evaluating performance. According to Kotler and Keller (2011), high customer satisfaction ratings are widely believed to be a leading indicator of a company's financial health. Many firms use customer satisfaction as a criterion for diagnosing product or service performance and even tie customer satisfaction ratings to executive and employee compensation (Anderson and Sullivan, 1993). Retailers therefore recognise that customer satisfaction plays a key role in a successful business strategy (Gomez et al, 2004) and it is therefore crucial for managers to understand what drives customer satisfaction (Martinez-Ruiz et al, 2010).

\section{Customer Satisfaction versus Perceived Service Quality}

Researchers often use the terms service quality and customer satisfaction interchangeably (Caruana, 2002). A number of distinctions can be made between customer satisfaction and perceived service quality. These include that satisfaction is a post-decision customer experience, while service quality is not (Caruana, 2002; Oliver, 1993). Expectations are also defined differently for satisfaction and perceived service quality. According to Boulding et al (1993), expectations reflect anticipated performance in satisfaction literature, while in service quality literature, expectations are conceptualised as a normative standard of future wants. Zeithaml and Bitner (2006) believe that service quality and customer satisfaction have certain things in common, but satisfaction is generally influenced by service quality. 


\section{J. Beneke \\ C. Hayworth \\ R. Hobson \\ Z. Mia}

Examining the effect of retail service quality dimensions on customer satisfaction and loyalty: The case of the supermarket shopper

The direct relationship between perceived service quality and customer satisfaction was first identified by Churchill and Suprenant (1982). Modelling perceived service performance as a direct predictor of satisfaction follows directly from the idea of a value-percept diversity (Szymanski and Henard, 2005). A multitude of studies have explored this relationship, with many (e.g. Tse and Wilton, 1988 and Halstead et al, 1994) arriving at the conclusion that the direct relationship between perceived service quality and satisfaction is not necessarily strong.

\section{Retail Service Quality Dimensions}

Retail stores have evolved from providing only physical products that address consumers' needs (Pan and Zinkhan, 2006) to offering a solution centre that integrates the sale of both physical products and valueadded services to attain competitive advantages (Davies et al, 2006). Cracking this code can lead to higher levels of customer retention, increased sales and, in turn, improved profits (Parasuraman, 1988).

Several studies, such as Long and McMellon (2004), Kim \& Jin (2002), Siu and Cheung (2001), Sweeney et al (1997) and Dabholkar et al (1996), have explored important dimensions of service quality within the retail sector. Specifically, within the supermarket sector, Vàzquez et al (2001) and Huang (2009) found Physical Aspects, Reliability, Personal Interaction, Problem Solving and Policy to be prominent. These dimensions are discussed below and have been adopted for the purpose of this study.

Physical Aspects: The concept of physical aspects is defined as the retail store appearance and store layout (Huang, 2009 and Vàzquez et al, 2001). The store environment, facilities and even imagery thereof have become factors which retailers can use to gain the competitive edge and influence customer satisfaction (Dabholkar et al, 1996). Physical environment plays a particularly important role in the service encounter of the grocery sector (Keillor et al, 2004) and exemplary retailers insist on store cleanliness, as well as a layout that enables customer orientation and product identification (Vàzquez et al, 2001).

According to Abu (2004), a well configured store layout that is easy to navigate will reduce a shopper's search time. Furthermore, Fisher et al. (2006) suggest that customers often do not find the products they seek, even if these products are within the store, due to poor store layout and that this leads to poor perceptions and the consumer turning to a competitor for solutions.

Perceptions of store appearance provide tangible clues about service quality (Yan et al, 2011; Dholakia \& Zhao, 2010; Bitner, 1990) and it has been noted that the appearance of the store is widely acknowledged as an essential determinant of the shopping experience (Dabholkar et al, 1996).

We hypothesise that:

H1: Physical aspects have a direct effect on customer satisfaction within the supermarket sector.

Reliability: The construct of reliability measures the store's ability to deliver the service that has been promised to customers accurately, and without error (Huang, 2009 \& Vàzquez et al, 2001). This implies that the store must practice a philosophy of getting it right first time, all the time. It must be able to keep its promises, meet deadlines and provide timely and accurate information to customers (Newman, 2001). Accurate information includes clear product pricing, as well as correct and precise information regarding the product (Vàzquez et al, 2001). Furthermore, reliability also refers to the store being able to have merchandise available when required. Interviews conducted by Dabholkar et al (1996) revealed that customers view reliability as a combination of keeping promises and 'doing it right'.

In the supermarket environment, limited availability of stock or long queues for the cash register refers to a lack of reliability on behalf of the retailer. It has been proved that lengthy waits for the cash register can result in consumers developing negative perceptions and decreased customer satisfaction (Rigopoulou et al, 2008; Grewal, 2003).

According to Zinn and Liu (2001), a stock outage can result in the consumer leaving the store and forgoing the purchase to search for the item elsewhere. Furthermore, in the long run, continuous stock 


\section{J. Beneke \\ C. Hayworth \\ R. Hobson \\ Z. Mia}

Examining the effect of retail service quality dimensions on customer satisfaction and loyalty: The case of the supermarket shopper

outages could have a negative impact on future patronage, and result in detrimental perceptions and negative word of mouth (Grant \& Fernie, 2008).

We hypothesise that:

H2: Reliability has a direct effect on customer satisfaction within the supermarket sector.

Personal Interaction: Sales assistants play a pivotal role in a customer service situation, with the most important attributes being store clerk attitude and treatment of customers (Gounaris, 2008; Gagliano, 1994). The customer service offered by sales personnel is perhaps the most highly visible attribute of the service encounter. Darian et al. (2001) noted the importance of sales staffs' knowledge regarding new products, prices, and other variations of store offerings, as well as commenting on the importance of treating the customer with respect.

Employees are often viewed as facilitators of the sales process, as they play a crucial role in improving the conversion ratio. Furthermore, employees also provide customers with assistance in navigating store aisles and selecting complementary items (in effect, cross-selling) when required (Jamal and Adelowore, 2008; Hennig-Thurau, 2004; Sweeney et al, 1997).

We hypothesise that:

H3: Personal interaction has a direct effect on customer satisfaction within the supermarket sector.

Problem Solving: Problem solving refers to the store's capability of handling returns and exchanges, as well as processing customers' problems and complaints. It includes the store's ability to express a sincere and genuine interest in solving the customer's problem and extends to the ability of staff to handle complaints directly and immediately (Swanson and Kelley, 2001; Vàzquez et al, 2001). Unless dealt with effectively, service failures have been shown to arouse dissatisfaction and anger, leading to disastrous consequences for the store (Chang et al, 2008).

There is evidence to support that customers have more favourable perceptions of stores that have effective problem solving processes in place (Huang, 2009). According to Lewis and Spyrakopoulos (2001), a good problem solving system will detect and solve problems, prevent dissatisfaction, and even encourage complaints.

Here, Michel (2001), Halstead and Page (1992) and Singh and Widing (1981) found that dissatisfied customers were more likely to repurchase when their complaints were dealt with satisfactorily. It is therefore in the best interest of the store to ensure that adequate and effective measures are implemented in order to facilitate problem solving for the consumer. These measures can take the form of customer care lines, customer service desks, helpful staff or even a website. Moreover, it has also been found that the post-transaction service offered by the store builds credibility and influences the favourable perception of consumers in the long term (Lindquist, 1974).

We hypothesise that:

H4: Problem solving has a direct effect on customer satisfaction within the supermarket sector.

Policy: Store policy refers to a store's decisions ('policy') concerning the depth and breadth of their merchandise, their loyalty programs and credit facilities, operating hours, parking facilities and additional customer services offered. Here, it has been found that stores endowed with good facilities are more likely to secure a favourable consumer perception (Thang and Tan, 2003). Customers expect retailers to be supportive and thus any service mechanism that suggests empathy and understanding is likely to impact favourably on perceived service quality and satisfaction (Dabholkar et al, 1996).

Brady and Cronin (2001) state that the evaluation of quality of service should include an evaluation on the performance of the physical goods offered to customers and they have therefore been introduced under policy. When shoppers perceive that the store offers a wide product assortment and that the products offer good value, they feel positive emotions like pleasure, excitement, contentment, pride, and 


\section{J. Beneke \\ C. Hayworth \\ R. Hobson \\ Z. Mia}

Examining the effect of retail service quality dimensions on customer satisfaction and loyalty: The case of the supermarket shopper

satisfaction (Yoo, 1998). Stores that are perceived as having superior merchandising are likely to be preferred by consumers (Thang and Tan, 2003).

The evaluation of the performance of the goods on offer also includes the store's ability to stock a wide range of products; the freshness of meat, fruit and vegetables; the assortment of fresh produce available as well as high quality of private label brands (Vàzquez et al, 2001). Failing to meet the expectations of the consumer in any of the aforementioned areas could result in the consumer experiencing lower levels of satisfaction. It has been indicated that continuous complaints of inconsistent produce quality could result in negative perceptions regarding the store (Bruhn and Grebitus, 2007) and hence lead to reduced levels of satisfaction.

We hypothesise that:

H5: Store policy has a direct effect on customer satisfaction within the supermarket sector.

Store Loyalty: Store loyalty provides the foundation of a company's sustained competitive edge, and is a crucial component of a company's growth and performance (Lee and Cunningham, 2001; Reichheld, 1996). Researchers suggest that store loyalty is a key variable in explaining customer retention (Pritchard and Howard, 1997) and is determined by a combination of repeat purchase level and a general level of attachment (Bodet, 2008 \& Dick and Basu, 1994). The latter relates to an individual customer's attitude towards a product, service or organisation (Hallowell, 1996). Other researchers suggest that store loyalty is a behavioural construct. This includes customer retention, repeat purchases and positive word of mouth (Hallowell, 1996; Liu and Wu, 2007). As these differences are rather slight, store loyalty and retention will be considered synonymous in the context of this study.

Whilst there is considerable evidence that customer satisfaction is correlated with loyalty, most scholars are of the view that not all satisfied customers will be loyal; neither will all dissatisfied customers abandon a retail chain due to dissatisfaction with a particular store (Vazquez-Carrasco and Foxall, 2006; Ellram et al, 1999). Shankar et al (2003) suggest that if customers have a negative experience and become dissatisfied with a service provider, they might gain a higher level of satisfaction by switching to a new provider. However, in this instance, the customer risks incurring losses in the form of loyalty benefits, such as emotional investment and the benefits lost from a rewards program. In addition, he/she may face a potentially unfamiliar service encounter with the new company. These factors therefore act as a deterrent.

Yang and Zhu (2006) expand on the relationship between satisfaction and loyalty. The authors argue that the relationship is influenced by the competitive environment of the market. In markets where the competition is not intense, customers are likely to remain loyal despite their levels of satisfaction. On the contrary, in markets where competition is intense, a slight drop in satisfaction will cause a considerable drop in loyalty. This ultimately results in the customer switching stores or even retail chains (Gomez et al, 2004).

We hypothesise that:

H6: Customer satisfaction has a direct effect on store loyalty within the supermarket sector. 


\section{J. Beneke \\ C. Hayworth \\ R. Hobson \\ Z. Mia}

Examining the effect of retail service quality dimensions on customer satisfaction and loyalty: The case of the supermarket shopper

Figure 1: Conceptual Model

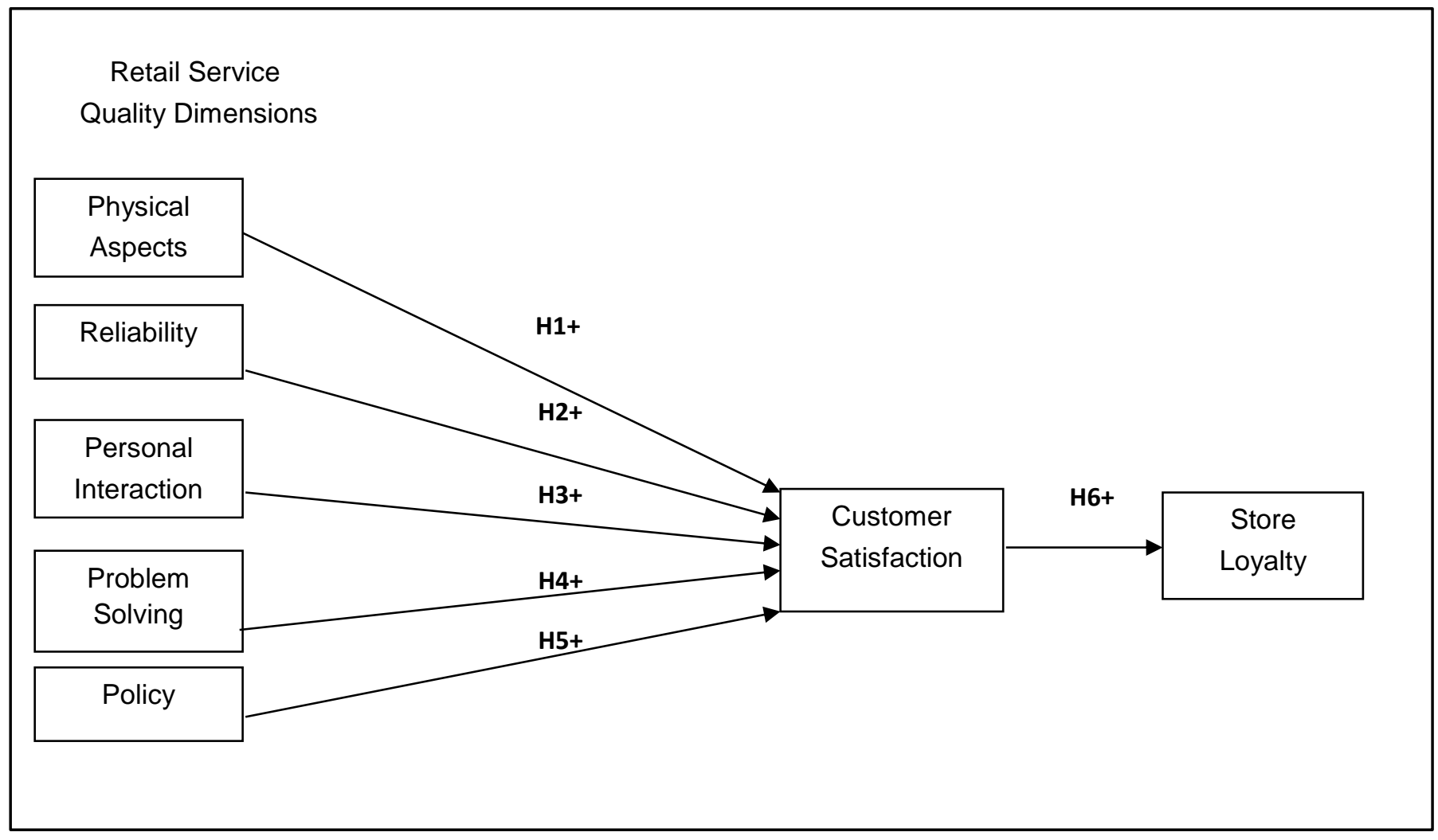

\section{METHODOLOGY}

\section{Survey}

Due to this being an independent study and in order to cast the net as wide as possible, the researchers were not able to obtain a specific list of supermarket shoppers. Hence, a non-probability technique using convenience sampling was used to collect the data in both face-to-face and online environments. In terms of the former, researchers visited regional shopping malls and other high traffic locations in a major metro pole. In terms of the latter, a web site was set up to allow respondents to complete the questionnaire at their leisure. The data was then stored on the server and retrieved at the end of the survey period. This dual approach was beneficial in that less affluent customers were typically surveyed at malls, whilst the online component encapsulated many medium to high end shoppers.

A pre-test was conducted in order to ensure that the questionnaire was clear, understandable and free of errors. Face validity was confirmed and the questionnaire was thereafter distributed to a small sample of 57 people to complete. Once the feedback had been analysed and minor problems addressed, the questionnaire was deemed ready for final distribution. In total, 307 responses were collected, with 160 of these being obtained through the online survey.

\section{Path Modelling}

The hypothesised direct and mediated relationships specified in the conceptual model were tested using Partial Least Squares (PLS) analysis through SmartPLS 2.0. PLS has become a popular alternative to using Structural Equation Modelling (SEM) for latent variable modelling due to its acclaimed predictive power in exploratory research (Henseler et al, 2010). Furthermore, it is conducive to application in 

J. Beneke
C. Hayworth
R. Hobson
Z. Mia

Examining the effect of retail service quality dimensions on customer satisfaction and loyalty: The case of the supermarket shopper

emerging markets, which tend to exhibit higher degrees of heterogeneity, due to less onerous assumptions about the data (Hair et al, 2010).

\section{Sample Biases}

The sample consisted of individuals who claimed to be regular shoppers at mainstream supermarket chains in the country. The sample was slightly skewed in favour of female respondents, younger adults (a mean age of 32 and standard deviation of 12.4 were recorded), and respondents who earned a middle to high level of income (30\% of the respondents earned under R 3500 per month, whereas $39 \%$ earned over R 13000 per month). In keeping with the above mentioned demographics, the dominant ethnic group was Caucasian respondents, followed by Asian/Indian respondents, and thereafter black African and mixed race respondents. Whilst it should be acknowledged that these biases were present in the sample, they were not deemed to be serious impediments for the empirical component of the study. For example, it is to be expected that Caucasians will have higher representivity in the sample than the national census. The segmented nature of South Africa's population means that many shopping malls tend to attract relatively affluent Caucasian (white) shoppers, whereas less affluent black African consumers are more prone to shopping at smaller, independent stores in peri-urban areas. Nonetheless, Analysis of Variance (ANOVA) was also used to control for this, where only marginal differences were observed between the various demographic cohorts.

\section{RESULTS}

\section{Reliability Analysis}

In order to test the internal reliability of the constructs that were used, a series of Item Reliability tests were conducted. Cronbach Alphas of 0.6 and above are deemed acceptable in emerging markets (Burgess \& Steenkamp, 2006) although the researchers used their discretion and included the Reliability construct $(0.58)$ as it only marginally missed the critical threshold. The respective Cronbach Alphas are reflected in Table 1.

Table 1: Item Reliability Analysis Results

\begin{tabular}{|l|l|l|}
\hline Scale & Manifest Variables & $\begin{array}{l}\text { Cronbach Alpha } \\
(\alpha)\end{array}$ \\
\hline Physical Appearance & 4 & 0.64 \\
\hline Reliability & 4 & 0.58 \\
\hline Personal Interaction & 3 & 0.79 \\
\hline Problem Solving & 3 & 0.77 \\
\hline Policy & 4 & 0.60 \\
\hline Customer Satisfaction & 5 & 0.68 \\
\hline Store Loyalty & 5 & 0.61
\end{tabular}

\section{Measurement Model - Convergent \& Discriminant Validity}

Convergent and discriminant validity were ascertained through Confirmatory Factor Analysis (detailed in Table 2) and the Fornell-Larcker test, respectively. In the case of the CFA, only one item ("Difficult to Reach") was removed as it failed to load on the factor (i.e. Store Loyalty). 

J. Beneke
C. Hayworth
R. Hobson
Z. Mia

Examining the effect of retail service quality dimensions on customer satisfaction and loyalty: The case of the supermarket shopper

Table 2: Confirmatory Factor Analysis including Scale Items

\begin{tabular}{|c|c|c|c|}
\hline Construct & Scale Items & T-statistic & $\begin{array}{l}\text { Significant } \\
\text { at the } 5 \% \\
\text { level? }\end{array}$ \\
\hline $\begin{array}{l}\text { Physical } \\
\text { Appearance }\end{array}$ & $\begin{array}{l}\text { "The overall appearance of a store" } \\
\text { "Clean shopping environment and efficient running" } \\
\text { "A store design that enables me to move around with ease" } \\
\text { "A layout that allows me to easily find the products I need" }\end{array}$ & $\begin{array}{l}13.08 \\
7.99 \\
12.60 \\
12.60\end{array}$ & $\begin{array}{l}\text { Yes } \\
\text { Yes } \\
\text { Yes } \\
\text { Yes }\end{array}$ \\
\hline Reliability & $\begin{array}{l}\text { "Correct and updated information on sales promotions" } \\
\text { "The length of time I have to wait in a queue" } \\
\text { "There are always stocks of products that I desire" } \\
\text { "Product prices are clearly visible" }\end{array}$ & $\begin{array}{l}10.47 \\
10.72 \\
7.36 \\
17.23\end{array}$ & $\begin{array}{l}\text { Yes } \\
\text { Yes } \\
\text { Yes } \\
\text { Yes }\end{array}$ \\
\hline $\begin{array}{l}\text { Personal } \\
\text { Interaction }\end{array}$ & $\begin{array}{l}\text { "The staff have enough knowledge to answer my questions" } \\
\text { "The staff are friendly and polite" } \\
\text { "The staff are always willing to help me" }\end{array}$ & $\begin{array}{l}28.07 \\
17.70 \\
42.31\end{array}$ & $\begin{array}{l}\text { Yes } \\
\text { Yes } \\
\text { Yes }\end{array}$ \\
\hline $\begin{array}{l}\text { Problem } \\
\text { Solving }\end{array}$ & $\begin{array}{l}\text { "The store deals with my queries and complaints } \\
\text { professionally" } \\
\text { "The store is efficient in resolving my questions and problems" } \\
\text { "Good returns policies" }\end{array}$ & $\begin{array}{l}36.96 \\
29.13 \\
15.32\end{array}$ & $\begin{array}{l}\text { Yes } \\
\text { Yes } \\
\text { Yes }\end{array}$ \\
\hline Policy & $\begin{array}{l}\text { "A wide assortment of quality and fresh merchandise on the } \\
\text { shelves" } \\
\text { "Convenient hours of operation" } \\
\text { "The availability of extra facilities such as toilets, payphones } \\
\text { and working trolleys" } \\
\text { "Convenient and safe parking facility available" }\end{array}$ & $\begin{array}{l}9.09 \\
5.46 \\
5.69 \\
15.63\end{array}$ & $\begin{array}{l}\text { Yes } \\
\text { Yes } \\
\text { Yes } \\
\text { Yes }\end{array}$ \\
\hline Satisfaction & $\begin{array}{l}\text { "I am satisfied with a supermarket store whose prices are } \\
\text { competitive" } \\
\text { "The quality of my shopping experience allows me to form an } \\
\text { opinion of the supermarket" } \\
\text { "I am extremely happy when the quality of the shopping } \\
\text { experience delivered is of a high standard" } \\
\text { "I become irritated and angry when the quality of products and } \\
\text { services that I receive is poor" } \\
\text { "I am satisfied with a supermarket store that always meets my } \\
\text { needs" }\end{array}$ & $\begin{array}{l}12.21 \\
14.19 \\
14.36 \\
13.62 \\
15.10\end{array}$ & $\begin{array}{l}\text { Yes } \\
\text { Yes } \\
\text { Yes } \\
\text { Yes } \\
\text { Yes }\end{array}$ \\
\hline $\begin{array}{l}\text { Store } \\
\text { Loyalty }\end{array}$ & $\begin{array}{l}\text { "When I am satisfied with the quality of the shopping } \\
\text { experience, I continue shopping at that supermarket store" } \\
\text { "If I have a bad experience at a supermarket, I am likely to tell } \\
\text { someone about it" } \\
\text { "When I am extremely satisfied with my shopping experience, I } \\
\text { am likely to tell someone about it" } \\
\text { "If I am satisfied with the quality of offerings of a supermarket, I } \\
\text { will continue buying from there even if it is difficult to reach" } \\
\text { "If customer service of a competing store is better, I am willing } \\
\text { to shop there" }\end{array}$ & $\begin{array}{l}12.22 \\
7.72 \\
12.58 \\
1.45 \\
9.63\end{array}$ & $\begin{array}{l}\text { Yes } \\
\text { Yes } \\
\text { Yes } \\
\text { No }\end{array}$ \\
\hline
\end{tabular}



J. Beneke
C. Hayworth
R. Hobson
Z. Mia

Examining the effect of retail service quality dimensions on customer satisfaction and loyalty: The case of the supermarket shopper

\section{Structural Model}

The structural model is made up of the main constructs being tested and the relationships between them. Table 3, below, tabulates the PLS output generated for the direct relationships.

Table 3: PLS output testing the relationships

\begin{tabular}{|l|}
\hline Hypotheses \\
\hline 1) Physical Aspects to Satisfaction \\
\hline 2) Reliability to Satisfaction \\
\hline 3) Personal interaction to Satisfaction \\
\hline 4) Problem Solving to Satisfaction \\
\hline 5) Policy to Satisfaction \\
\hline 6) Customer Satisfaction to Loyalty \\
\hline
\end{tabular}

\begin{tabular}{|l|l|l|l|}
\hline Beta & Std Error & t-Stat & Significant @ 10\% level \\
\hline 0.30 & 0.06 & 5.27 & Yes $(\mathrm{P}<0.01)$ \\
\hline 0.10 & 0.07 & 1.42 & No \\
\hline 0.14 & 0.07 & 1.93 & Yes $(\mathrm{P}<0.1)$ \\
\hline 0.01 & 0.07 & 0.19 & No \\
\hline 0.04 & 0.06 & 0.60 & No \\
\hline 0.38 & 0.06 & 6.82 & Yes $(\mathrm{P}<0.01)$ \\
\hline
\end{tabular}

Table 4 reflects the determination of the respective hypotheses. This is visually depicted in the conceptual model in figure 2. The discussion, below, considers the outcome of each hypothesis in turn.

Table 4: Outcome of hypothesised relationships

\begin{tabular}{|l|l|}
\hline H. No. & $\begin{array}{l}\text { Hypothesis } \\
\text { Physical aspects have a direct effect on customer satisfaction within the } \\
\text { supermarket sector. }\end{array}$ \\
\hline $\mathbf{2}$ & $\begin{array}{l}\text { Reliability has a direct effect on customer satisfaction within the supermarket } \\
\text { sector. }\end{array}$ \\
\hline $\mathbf{3}$ & $\begin{array}{l}\text { Personal interaction has a direct effect on customer satisfaction within the } \\
\text { supermarket sector. }\end{array}$ \\
\hline $\mathbf{4}$ & $\begin{array}{l}\text { Problem solving has a direct effect on customer satisfaction within the } \\
\text { supermarket sector. }\end{array}$ \\
\hline $\mathbf{5}$ & $\begin{array}{l}\text { Store policy has a direct effect on customer satisfaction within the supermarket } \\
\text { sector. }\end{array}$ \\
\hline 6 & $\begin{array}{l}\text { Customer satisfaction has a direct effect on store loyalty within the supermarket } \\
\text { sector. }\end{array}$
\end{tabular}

\section{Accepted/} Rejected

Accepted

Rejected

Accepted

Rejected

Rejected

Accepted 


\section{J. Beneke \\ C. Hayworth \\ R. Hobson}

Examining the effect of retail service quality dimensions on customer

satisfaction and loyalty: The case of the supermarket shopper

Figure 2 depicts an updated version of conceptual model, reflecting the underlying constructs which contribute to customer satisfaction and loyalty to supermarkets.

The red lines are used to illustrate the statistically significant relationships (at the $10 \%$ significance level), whereas the black lines are used to illustrate the statistically insignificant relationships.

\section{Figure 2: Empirically Tested Conceptual Model}

Retail Service Quality

Dimensions
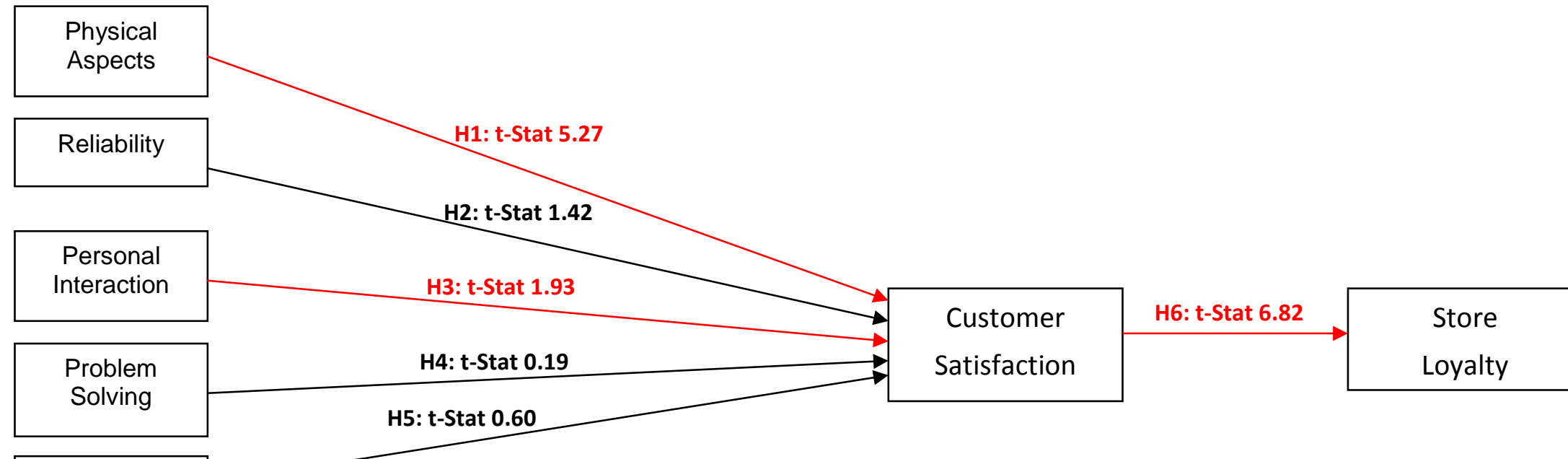

Policy 


\section{J. Beneke \\ C. Hayworth \\ R. Hobson \\ Z. Mia}

Examining the effect of retail service quality dimensions on customer satisfaction and loyalty: The case of the supermarket shopper

\section{DISCUSSION}

The results from the PLS analysis into the path model show that a statistically significant relationship exists between only two of the five Retail Service Quality dimensions and Satisfaction at or below the $10 \%$ significance level. These two factors are Physical Appearance and Personal Interaction. Reliability was shown to be very weakly linked to Satisfaction (i.e. significant only at the $20 \%$ significance level). The remaining two factors, Problem Solving and Policy, do not appear to have a significant effect on Satisfaction.

As anticipated, the analysis revealed that a strong relationship existed between Customer Satisfaction and Loyalty. This was not at all surprising, as this relationship has been well documented in previous studies.

Physical Aspects was found to be the most important predictor of Customer Satisfaction. The effect was considerably stronger than any of the other relationships explored. This reinforces the notion that the physical environment needs to be clean, well-structured and adequately maintained. As the mainstay of supermarket stores is grocery sales, it appears that customers want to shop in an environment which is deemed safe and healthy. Furthermore, the design needs to be optimised so as to maximise convenience. As grocery shopping is perceived as unglamorous (even a grudge purchase) by many consumers, it would appear that consumers are seeking a hassle free experience.

Personal Interaction was also found to be significant. This factor relates to the way in which customers perceive the staff. It would appear that customers cherish an environment in which staff are knowledgeable, friendly and willing to assist. This is an issue which has plagued many supermarket chains where staff are paid minimum wage and are employed on a casual basis. Connected to the convenience issue highlighted above, staff should be present on the shop floor to direct customers when lost and navigational assistance is required. Cashiers are considered by some to represent the 'face' of the brand - hence a positive experience at the till point clearly makes a noteworthy impression on the customer.

Reliability was found to be very weakly connected to customer satisfaction, however no statistical significance was recorded at either the $5 \%$ or $10 \%$ level, meaning that no meaningful association was found to exist. This factor considered issues such as stock availability, the visibility of shelf prices, as well as information pertaining to sales promotions and queue lengths. It is surmised that most supermarket stores are very similar in this regard, and that customers therefore do not see sufficient grounds for differentiation. Furthermore, it is possible that many may have come to expect average service delivery in this regard, and hence lowered expectations to match performance. For these reasons, customers may not see this as being a noteworthy antecedent of customer satisfaction.

Somewhat counter-intuitively, no evidence was found to support the notion that Problem Solving and Policy were significant influencers of customer satisfaction. Here, problem solving (considering complaints and returns), was deemed somewhat irrelevant. Again, this may be due to apathy on the part of the consumer. Anecdotal evidence suggests that many customers would rather dispose of an unwanted grocery item than spend time in returning it. It is likely that many customers have never bothered to submit a complaint or return groceries; therefore this factor may be superfluous to them. Lastly, Policy (relating to issues such as parking facilities, hours of operation and the availability of facilities such as toilets and payphones) was, likewise, not highlighted as an issue of importance. Basic expectations of consumers may be guiding their judgement here. The authors surmise that a large degree of standardisation across the different supermarket chains has led many consumers to take the status quo for granted. In short, retailers who fail to comply with the fundamental needs of the target market are unlikely to experience repeat patronage. 


\section{J. Beneke \\ C. Hayworth \\ R. Hobson \\ Z. Mia}

Examining the effect of retail service quality dimensions on customer satisfaction and loyalty: The case of the supermarket shopper

\section{CONCLUSION}

It appears that supermarkets in South Africa should therefore place a premium on their premises, as well as the reception and treatment of their customers. The aesthetic appeal of the supermarket needs to be favourable, the layout of merchandise should be logical and orderly, and a high degree of cleanliness ought to be maintained at all times. It may well be worth investing in marketing research in order to ensure that expectations are met, and exceeded, in this regard. Furthermore, staff should adopt a friendly disposition, and possess the required store knowledge through internal training programmes.

Anecdotal evidence suggests that consumers are swimming in a 'sea of sameness'. Here, a large degree of standardisation has developed between the chains, as they endeavour to match like-for-like. It is possible that consumer expectations may have been moulded into accepting the status quo. This is particularly pertinent to the majority of customers, who are unlikely to have travelled abroad and experienced shopping at international supermarket chains.

The emergence of WalMart in the South African retail environment may provide added impetus to invigorate the supermarket sector. The company has a strong reputation for being a fearsome competitor and offering impressive value to customers. Whilst their merchandise is heavily discounted, the retailer also attempts to provide good service, for example through the 'people greeter' situated at store entrances and electronic checkout facilities to minimise lengthy queues at till points. Customers may not necessarily expect red carpet treatment from their discount supermarket store - but that's a poor excuse for taking the customer base for granted.

\section{REFERENCES}

Abu, N. (2004). "Service Quality Dimensions: A Study on Various Sizes of Grocery Retailers. A conceptual Paper", Proceedings of IBBC 2004.

Anderson, E. W., Fornell, C., Lehmann, D. R. (1994), "Customer satisfaction, market share, and profitability: Findings from Sweden", Journal of Marketing, Vol. 58, pp. 53-66

Anderson, E.W. and Sullivan, M.W. (1993), "The Antecedents and Consequences of Customer Satisfaction for Firms", Marketing Science, Vol. 12, pp. 125-143.

Bitner, M.J., (1990). "Evaluating Service Encounters: The Effects of Physical Surroundings and Employee Responses", Journal of Marketing, Vol. 54, pp. 69-82

Blodgett, J., Wakefield, K., and Barnes, J. (1995), "The effects of customer service on consumer complaining behaviour," Journal of Services Marketing, Vol. 9

Bodet, G. (2008), "Customer Satisfaction and Loyalty in Service: Two concepts, four constructs, several relationships", Journal of Retailing and Consumer Services, Vol. 15, pp. 156-162.

Boulding, W., Kalra, A., Staelin, R., Zeithaml, V. (1993). "A dynamic process model of service quality: From expectations to behavioural intentions", Journal of Marketing Research, Vol. 30, pp. 727.

Brady, M. K., and Cronin Jr., J.J. (2001), "Customer orientation: Effects on customer service perceptions and outcome behaviours", Journal of Service Research, Vol. 3, No. 3

Bruhn, M. and Grebitus, C. (2007). "Food quality from a customer's perspective.", In Theuvsen, L., Spiller, A., Peupert, M. and Jahn, G. (eds), Quality management in food chains., Netherlands: Wagenheim Academic Publishers, pp. 243-254. 

J. Beneke
C. Hayworth
R. Hobson
Z. Mia

Examining the effect of retail service quality dimensions on customer satisfaction and loyalty: The case of the supermarket shopper

Burgess, S. M., Steenkamp, J. E. M. (2006). "Marketing renaissance: How research in emerging markets advances marketing science and practice", Journal of Research in Marketing, Vol. 23, pp. 337-356

Campo, K., Gijsbrechts, E. \& Misol, P. (2000), “Towards Understanding Consumer Responses to Stock-Outs", Journal of Research, Vol. 79, No. 2, pp. 219-242

Caruana, A. (2002), "Service loyalty - The effects of service quality and the mediating role of customer satisfaction", European Journal of Marketing, Vol. 36, No. 7/8, pp. 811-828

Chang, H., Lee, J., and Tseng, M. (2008), "The influence of service recovery on perceived justice under different involvement level - an evidence of retail industry," Contemporary Management Research, Vol. 4, No. 1

Churchill, G. A. and Surprenant, C. (1982). "An Investigation into the Determinants of Customer Satisfaction?", Journal of Marketing Research, Vol. 19, pp. 491-504

Dabholkar, P.A., Thorpe, D.I., and Rentz, J.O. (1996), "A measure of service quality for retail stories: scale development and validation", Journal of the Academy of Marketing Science, Vol. 24 No.1, pp.3-16.

Darian, J.C., Tucci, L.A. and Wiman, A.R. (2001), "Perceived salesperson service attributes and retail patronage intentions", International Journal of Retail \& Distribution Management, Vol. 29, pp. 205-213

Davies, A., Brady, T., and Hobday, M., (2006), "Charting a Path toward Integrated Solutions", Sloan Management Review, Vol. 47, No.3, pp. 39-48

Dholakia, R.R. and Zhao, M. (2010). "Effects of online store attributes on customer satisfaction and repurchase intentions", International Journal of Retail \& Distribution Management, Vol. 38, No. 7, pp. 482 - 496

Dick, S.A. and Basu, K. (1994), "Customer Loyalty: toward and integrated conceptual framework", Journal of the Academy of Marketing Science, Vol. 22, pp. 99-113

Ellram, L.M., La Londe, B.J. and Webber, M.M. (1999), "Retail logistics", International Journal of Physical Distribution \& Logistics Management, Vol. 29, pp. 477-494

Erdem, O., Oumlil, A.B. and Tuncalp, S. (1999), "Consumer values and the importance of store attributes", International Journal of Retail \& Distribution Management, Vol. 27, pp. 137 - 144

Fisher, M.L., Krishnan, J., and Netssine, S. (2006). "Retail Store Execution: An Empirical Study". $A$ Conceptual Paper

Fonseca, J. (2009). “Customer Satisfaction Study via a Latent Segmentation Model”, Journal of Retailing and Consumer Services, Vol. 16, pp. 352-359

Fornell, C. (1992). "A national customer satisfaction barometer: The Swedish Experience", Journal of Marketing, Vol. 56, pp. 6-21

Gagliano, K.B., and Hathcote, J. (1994), "Customer expectations and perceptions of service quality in retail apparel specialty stores", The Journal of Services Marketing, Vol. 8, pp. 60 - 70

Ganesh, J., Arnold, M.J., \& Reynolds, K.E. (2000), "Understanding the Customer Base of Service Providers: An Examination of the Differences Between Switchers and Stayers", Journal of Marketing, Vol. 64, No. 3, pp. 65-87 
Garbarino, E., \& Johnson, M.S. (1999). "The Different Roles of Satisfaction, Trust, and Commitment in Customer Relationships", Journal of Marketing, Vol. 63, No. 2, pp. 70-87

Gomez, M. I., McLaughlin, E. W, Wittink, D. R. (2004), "Customer satisfaction and retail sales performance: an empirical investigation", Journal of Retailing, Vol. 80, pp. 265-278

Gounaris, S. (2008). "Antecedents of internal marketing practice: some preliminary empirical evidence", International Journal of Service Industry Management, Vol. 19, No. 3, pp. 400 - 434

Grant, D.B. and Fernie, J. (2008). "Research note: Exploring out-of-stock and on-shelf availability in non-grocery, high street retailing", International Journal of Retail \& Distribution Management, Vol. 36, No. 8, pp. 661 - 672

Grewal, D., Baker J., Levy, M. and Voss, G.B. (2003), "The effect of wait expectations and store atmosphere evaluations on patronage intentions in service-intensive retail stores", Journal of Retailing, Vol. 79, pp. $259-268$

Hair, J., Black, W., Babin, B. and Anderson, R. (2010). Multivariate Data Analysis, 7th edition. New Jersey: Prentice Hall.

Hallowell, R. (1996), "The relationships of customer satisfaction, customer loyalty, and profitability: an empirical study", International Journal of Service Industry Management, Vol. 7, pp. 27-42

Halstead, D., Hartman, D. and Schmidt, S. (1994). "Multisource effects on the satisfaction formation process". Journal of the Academy of Marketing Science, Vol. 22, No. 2, pp. 114-129.

Halstead, D. and Page, T.J. (1992). "The effects of satisfaction and complaining behaviour on consumer repurchase intentions", Journal of Consumer Satisfaction, Vol. 5, pp. 1-11

Hennig-Thurau, T. (2004), "Customer orientation of service employees: Its impact on customer satisfaction, commitment, and retention", International Journal of Service Industry Management, Vol. 15, pp. 460-478

Henseler, J., Ringle, C. and Sinkovics, R. (2010). "The use of Partial Least Squares path modelling in international marketing" New Challenges to International Marketing, Vol. 20, pp. 277-319.

Homburg, C. and Giering, A. (2001), "Personal characteristics as moderators of the relationship between customer satisfaction and loyalty, an empirical analysis" Psychology \& Marketing, Vol. 18 , No. 1, pp. 43-66

Huang, M. (2009). "Using service quality to enhance the perceived quality of store brands," Total Quality Management \& Business Excellence, Vol. 20, No. 2, pp. 241-252.

Huber, F., Herrmann, A., Wricke, M. (2001). "Customer satisfaction as an antecedent of price acceptance: results of an empirical study", Journal of Product \& Brand Management, Vol. 10 No.3, pp.160-9

Jamal, A and Adelowore, A. (2008), "Customer-employee relationship: The role of self-employee congruence", European Journal of Marketing, Vol. 42, pp. 1316-1345

Kasper, H. (1988). "On problem perception, dissatisfaction and brand loyalty", Journal of Economic Psychology, Vol. 9, No.3, pp. 387-397

Keillor, B. D., Hult, G. T. M., and Kandemir, D. (2004). "A study of the service encounter in eight countries," Journal of International Marketing, Vol.12, No.1 

J. Beneke
C. Hayworth
R. Hobson
Z. Mia

Examining the effect of retail service quality dimensions on customer satisfaction and loyalty: The case of the supermarket shopper

Kim, S. and Jin, B. (2002), "Validating the retail service quality scale for US and Korean customers of discount stores: an exploratory study", Journal of Services Marketing, Vol. 16, No. 3, pp. 223 237

Knox, S.D. and Denison, T.J. (2000), "Store Loyalty: its impact on retail revenue. An empirical study of purchasing behaviour in the UK", Journal of Retailing and Consumer Services, Vol. 7, pp. 3345

Kotler, P. and Keller, K.L. (2011). Marketing Management, 14th ed. New Jersey: Pearson Education Inc

Lee, M. and Cunningham, L. F. (2001). "A cost/benefit approach to understanding service loyalty", Journal of Services Marketing, Vol. 15, pp. 113-130

Lewis, B., and Spyrakopoulos, S. (2001). "Banking; Consumer attitudes; Customer service; Service quality; Customer satisfaction”, International Journal of Bank Marketing. Vol. 19, pp. 37-48

Lindquist, J.D.( 1974). "Meaning of image: survey of empirical and hypothetical evidence," Journal of Retailing, Vol. 50, No.4, pp. 29-38

Liu, T.C. and Wu, L.W. (2007), "Customer retention and cross-buying in the banking industry: An integration of service attributes, satisfaction and trust", Journal of Financial Service Marketing, Vol. 12, pp. 132-145

Long, M. and McMellon, C. (2004), "Exploring the determinants of retail service quality on the Internet", Journal of Services Marketing, Vol. 18, No. 1, pp. $78-90$

Martinez-Ruiz, M., Jimenez-Zarco, A. and Izquierdo-Yusta, A. (2010). "Customer Satisfaction's Key Factors in Spanish Grocery Stores: Evidence from hypermarkets and supermarkets", Journal of Retailing and Consumer Services, Vol. 17, pp. 278-285.

Marx, N.J.M.M. and Erasmus, A.C. (2006), "An evaluation of the customer service in supermarkets in Pretoria East, Tshwane Metropolis, South Africa", Journal of Family Ecology and Consumer Science, Vol. 34, pp. 56-68

Mazursky, D. and Jacoby, J. (1985), "Forming Impressions of Merchandise and Service Quality", C. Olson, 139-153. Lexington, MA: Lexington Books

Michel, S. (2001). "Analyzing service failures and recoveries: a process approach", International Journal of Service Industry Management, Vol. 12, No. 1, pp. 20 - 33

Newman, K. (2001). "Interrogating SERVQUAL: a critical assessment of service quality measurement in a high street retail bank", International Journal of Banking, Vol. 19, No. 3

Oliver, R.L. (1993). "A conceptual model of service quality and service satisfaction: compatible goals, different concepts". In Swartz, T.A., Bowen, D.E. and Brown, S.W. (eds), Advances in Services Marketing and Management: Research and Practice, Vol. 2, JAI Press, Greenwich, CT, pg. 65-85.

Oliver, R.L. (2010). "Satisfaction: A Behavioural Perspective on the Consumer", $2^{\text {nd }}$ edition. McGrawHill, New York

Pan, Y., and Zinkhan, G., (2006). "Determinants of Retail Patronage: A Meta-Analytical Perspective," Journal of Retailing, Vol.82, No. 3, pp. 229-243. 


\section{J. Beneke \\ C. Hayworth \\ R. Hobson \\ Z. Mia}

Examining the effect of retail service quality dimensions on customer satisfaction and loyalty: The case of the supermarket shopper

Parasuraman, A., Zeithaml, V.A and Berry, L.L. (1988). "SERVQUAL: a multiple-item scale for measuring consumer perceptions of service quality," Journal of Retailing, Vol. 64, No. 1, pp. $12-40$

Pritchard, M.P. and Howard, D.R. (1997), "Relative impact of performance and importance ratings on measurement of service quality", Journal of Travel Research, Spring, pp. 2-10

Reichheld, F. F. (2001). "The loyalty effect” revised edition. Boston: Harvard Business School Press

Rigopoulou, I., Tsiotsou, R. and Kehagias, J. (2008). Shopping Orientation-defined Segments based on Store-choice Criteria and Satisfaction: An empirical investigation. Journal of Marketing Management, Vol. 24, No. 9 \& 10, pp 979 - 995

Shankar, V., Smith, A.K. and Rangaswamy, A. (2003), "Customer satisfaction and loyalty in online and offline environments", International Journal of Marketing, Vol. 20, pp. 152 - 175

Singh, J., and Widing, E. (1981). "What occurs when consumers complain: a theoretical model for understanding satisfaction/dissatisfaction outcomes of complaint responses", European Journal of Marketing, Vol. 25 No.5, pp.30-46

Siu, N. and Cheung, J. (2001), "A measure of retail service quality", Marketing Intelligence \& Planning, Vol. 19 Iss: 2 , pp.88 - 96

Sivdaas, E. and Baker-Prewitt, J.L. (2000), "An examination of the relationship between service quality, customer satisfaction, and store loyalty", International Journal of Retail \& Distribution Management, Vol. 28, pp. 73-82

Swanson, S.R., and Kelley, S.W. (2001)."Service recovery attributions and word-of-mouth intentions", European Journal of Marketing, Vol. 35 No.1, pp.194-211

Sweeney, J., Soutar G., Johnson, L. (1997). "Retail service quality and perceived value”, Journal of Retailing and Consumer Services, Vol. 4, No. 1, pp. 39-38

Szymanski, D. and Henard, D. (2005). "Customer satisfaction: a meta-analysis of the empirical evidence", Journal of the Academy of Marketing Science”, Vol. 29, No. 1, pp. 16-35

Tepeci, M. (1999). "Increasing brand loyalty in the hospitality industry", International Journal of Contemporary Hospitality Management, Vol. 11, No. 5, pp. 223-230

Thang, D., and Tan, B. (2003). "Linking consumer perception to preference of retail stores: an empirical assessment of the multi-attributes of store image," Journal of Retailing and Consumer Services, Vol.10, pp. 193-200

Tse D. K., and Wilton P. C. (1988) "Models of consumer satisfaction formation: An extension”, Journal of Marketing Research, Vol. 25, No. 2, pp. 204-212

Varela-Neira, C., Vazquez-Casiellesa, R. and Iglesias, V. (2010). "Explaining Customer Satisfaction with Complaint Handling", International Journal of Bank Marketing, Vol. 28, No. 2, pp 88-112.

Vazquez-Carrasco, R and Foxall, G.R. (2006), "Positive vs. negative switching barriers: the influence of service consumers' need for variety", Journal of Consumer Behaviour, Vol. 2, pp. 367-379

Vàzquez, R., Rodrguez-Del Bosque, I.A., Ma Daz, A. and Ruiz, A.V. (2001), "Service quality in supermarket retailing: identifying critical service experiences", Journal of Retailing and Consumer Services, Vol. 8, pp. 1-14 

J. Beneke
C. Hayworth
R. Hobson
Z. Mia

Examining the effect of retail service quality dimensions on customer satisfaction and loyalty: The case of the supermarket shopper

Wong, A. and Sohal, A. (2003), "Service quality and customer loyalty perspectives on two levels of retail relationships", Journal of Service Marketing, Vol. 17, pp. 495-513

Yan, R., Yurchisin, J. and Watchravesringkan, K. (2011). "Does formality matter?: Effects of employee clothing formality on consumers' service quality expectations and store image perceptions", International Journal of Retail \& Distribution Management, Vol. 39, No. 5, pp. 346 - 362

Yang, S. and Zhu, Y. (2006). Customer Satisfaction Theory Applied in the Housing Industry: An Empirical Study of Low-Priced Housing in Beijing. Tsinghua Science \& Technology, Vol. 11, No. 6, pp. 667-674.

Yang, Z. and Peterson R.T. (2004), "Customer Perceived Value, Satisfaction, and Loyalty: The Role of Switching Costs", Psychology and Marketing, Vol. 21, pp. 799-822

Yoo, C., Park, J., and Maclnnis, D. (1998). "Effects of Store Characteristics and In-Store Emotional Experiences on Store Attitude," Journal of Business Research, Vol. 42, No. 3, pp. 253-263

Zeithaml, V.A. and Bitner, M.J. (2006), “Services Marketing”, 4th ed., McGraw-Hill, Maidenhead.

Zinn, W. and Liu, P.C. (2001), "Consumer responses to retail stockouts", Journal of Business Logistics, Vol. 22, pp. $49-71$ 